\title{
THE USE OF CELL FREE FETAL DNA [cff-DNA] AS NON-INVASIVE TECHNIQUES ON PATERNITY TEST [FORENSIC IDENTIFICATION]
}

\author{
Ahmad Yudianto \\ Master of Forensic Science, Postgraduate School \\ Human Genetic Laboratory, Institute of Tropical Disease \\ Airlangga University \\ 2017 \\ Correspondence, email : yudi4n6sby@yahoo.co.id
}

\begin{abstract}
The use of samples based on cell free foetal DNA [cff-DNA] in criminal cases (paternity test) in the future will be inevitable need. The cases related to forensic identification or other criminal cases are predicted to continue to rise. To overcome these problems, a practical solution would be the use of non-invasive techniques with samples derived from cell free foetal-DNA. The use of this material is expected to help the process of forensic identification (paternity test) to assist law enforcement in Indonesia.

The research has used cff-DNA in the context of a paternity test with a short tandem repeat combined DNA System/STR-CODIS. Cell free foetal DNA in the maternal circulation is promising new hope for forensic identification in cases of paternity.
\end{abstract}

Keywords : cell free foetal, paternity test, STR

\section{INTRODUCTION}

In the early 1990s, most of the world's scientists still believed that the existence of several layers of villous trophoblasts would be able to prevent the mixing of the foetal and maternal circulatory systems. On the other hand, however, several other scientists have begun to discover the fact that the barrier turns out to be penetrable by some foetal cells, causing them to enter into the maternal circulation. It was this fact that inspired Liao et al. (2014) to propose the theory that in a maternal pregnant body, there is naturally a traffic of molecules and even cells from the foetus to the maternal body and vice versa. Furthermore, research in the area of bidirectional traffic has been continuing to grow, and one of the topics growing very rapidly within this is cell-free foetal DNA (cff-DNA).

Foetal deoxyribonucleid acid in the maternal plasma has been relatively widely used in the medical world, one of which is for prenatal diagnoses, including (1) the diagnosis of several diseases associated with the $\mathrm{X}$ chromosome, (2) the diagnosis of foetal rhesus D and (3) the diagnosis of $\beta$-thalassemia (Bardenn, 2002). Most of the above-mentioned applications have focused on the presence of foetal DNA sequences thought to be strongly correlated with certain paternally-inherited disease-causing sequences (paternity tests).
Cell-free foetal DNA are foetal-derived DNA fragments that successfully penetrate the maternal circulation so that its presence can be detected by methods as DNA isolation from samples of maternal plasma. Initially, applications of cff-DNA have been limited only to determining types of rhesus disease and foetal sex. However, today, applications of cff-DNA are growing very rapidly as they begin to be used to detect the presence of specific markers for some types of trisomy in the foetus.

\section{METHODS}

The present study was a laboratory observation using DNA derived from maternal plasma by means of the polymerase chain reaction (PCR) method at STR loci (CSF1PO, THO1, TPOX and vWA). Samples were taken from the blood of volunteer first-semester pregnant women who have signed an informed consent form. The present study passed an ethics review and approval board. A total of $3 \mathrm{ml}$ of peripheral blood was centrifuged at 2,000 rpm for $10 \mathrm{~min}$. Furthermore, the plasma and pellet phases were extracted in to different tubes using the DNAzol method.

Subsequently, it was subjected to PCR amplification with the primer STR CODIS: CSF1PO: $\quad 5$ 'AACCTGAGTCTGCCAAGGACTAGC-3' \& 5'TTCCACACACCACTGGCCATCTTC-3'; THO1: 5'-CTGGGCACGTGAGGGCAGCGTCT-3' \& 5'-TGCCGGAAGTCCATCCTCACAGTC-3' TPOX: $\quad 5$ 'ACTGGCACAGAACAGGCATCTAGG-3' \&: 5'GGAGGAACTGGGAACCACACAGGT-3'.

The PCR thermal Cycler was set to the following amplification protocol for the locus.

CSF1PO: Initial denaturation $96^{\circ} \mathrm{C}-2 \mathrm{~min}$, [Subsequent denaturation $94^{\circ} \mathrm{C}-1 \mathrm{~min}$, Annealing $64^{\circ} \mathrm{C}-1 \mathrm{~min}$, Extension $70^{\circ} \mathrm{C}-1 \mathrm{~min}-30 \mathrm{sec}$

- $[(10 \mathrm{X})]$ : Denaturation $90^{\circ} \mathrm{C}-1$ min, Annealing $64^{\circ} \mathrm{C}-1$ min, Extension $70^{\circ} \mathrm{C}-1 \mathrm{~min}-30 \mathrm{sec}$

- $\quad[(20 \mathrm{X})]$ : Hold Step $4^{0} \mathrm{C}$.

THO1: Initial denaturation 960C -2 min 
- $\quad[(10 \mathrm{X})]:$ Subsequent denaturation $94{ }^{0} \mathrm{C}-1 \mathrm{~min}$, Annealing 640C -1 min, Extension $70^{\circ} \mathrm{C}-1$ min-30 sec, $[(30 \mathrm{X})]$ : Denaturation $90^{\circ} \mathrm{C}-$ $1 \mathrm{~min}$, Annealing $64^{\circ} \mathrm{C}-1 \mathrm{~min}$, Extension $\left.70^{\circ} \mathrm{C}-1 \mathrm{~min}-30 \mathrm{sec}\right]$, Hold Step $4^{0} \mathrm{C}$.

TPOX: Initial denaturation $96{ }^{\circ} \mathrm{C}-2 \mathrm{~min}$

- $\quad\left[\begin{array}{lll}( & 10 & \mathrm{X})\end{array} \quad\right.$ Subsequent denaturation $94{ }^{0} \mathrm{C}-1 \mathrm{~min}$, Annealing $\quad 64^{\circ} \mathrm{C} \quad-1 \quad \mathrm{~min}$, Extension $70^{\circ} \mathrm{C}-1 \mathrm{~min}-30 \mathrm{sec}$

- $\quad[(20 \mathrm{X})]$ : Denaturation $90^{\circ} \mathrm{C}-1$ min, Annealing $64^{\circ} \mathrm{C}-1 \mathrm{~min}$, Extension $\left.70^{\circ} \mathrm{C}-1 \mathrm{~min}-30 \mathrm{sec}\right]$, Hold Step $4^{0} \mathrm{C}$

\section{RESULTS}

The levels of DNA after the isolation of the DNA from maternal plasma and pellets prior to PCR amplification are as follows:

Table 1. Levels of DNA samples

\begin{tabular}{|c|c|c|}
\hline Sample & $\begin{array}{c}\text { maternal } \\
\text { pellet } \\
(\boldsymbol{\mu} \mathbf{g} / \mathbf{m l})\end{array}$ & $\begin{array}{c}\text { maternal plasma } \\
(\boldsymbol{\mu g} / \mathbf{m l})\end{array}$ \\
\hline 1 & 234,50 & 28,30 \\
\hline 2 & 213,45 & 24,50 \\
\hline 3 & 254,89 & 21,30 \\
\hline 4 & 203,55 & 22,87 \\
\hline 5 & 278,50 & 23,67 \\
\hline 6 & 224,35 & 27,55 \\
\hline
\end{tabular}

Table 1 shows the levels of DNA isolated from the peripheral blood of maternal plasma and pellet maternal samples. The level of DNA could still be used in DNA profiling. That requires a DNA level of approximately $20 \mu \mathrm{g} / \mathrm{ml}$ for typing (Butler et al, 2004 and Conner et al, 1992).
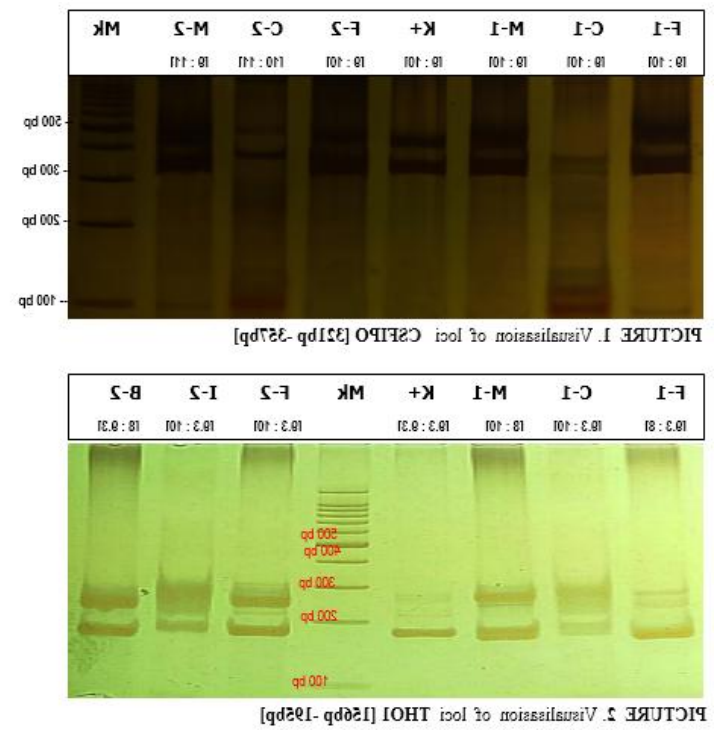

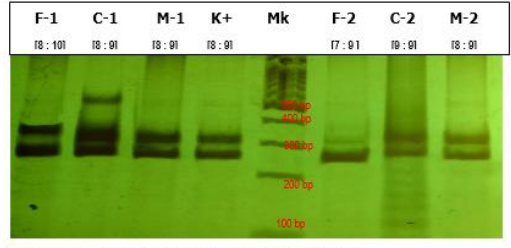

PICTURE 3. Visualisasion of loci TPOX [262bp-290bp]

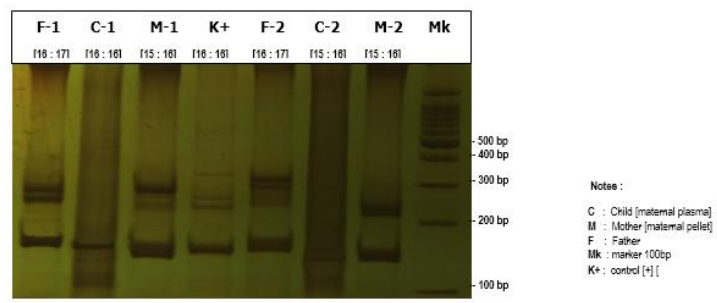

PICTURE 4. Visualisasion of loci vWA[123bp -171bp]

Table 2twelles of the sample

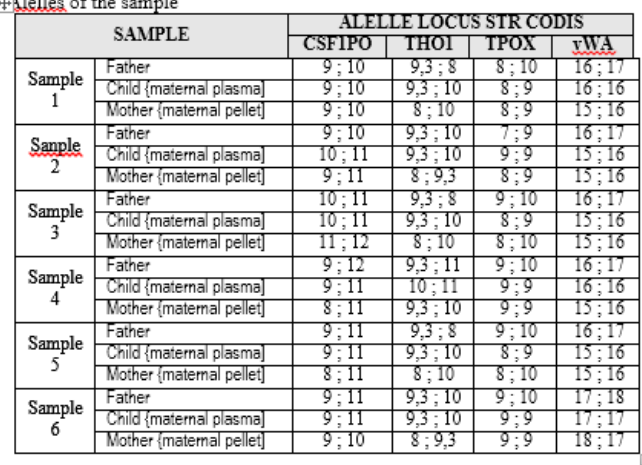

DISCUSSION

The theory is that in a maternal pregnant body, there is naturally traffic of molecules and even cells from the foetus to the maternal body and vice versa. Furthermore, research in the area of bidirectional traffic has been continuing to grow. One of the topics growing very rapidly is cell-free foetal DNA (cff-DNAs). Foetal DNA in the maternal plasma has been relatively widely used in the medical world, one of which is for prenatal diagnoses. Most of the above-mentioned applications have focused on the presence of foetal DNA sequences thought to be strongly correlated with certain paternally-inherited disease-causing sequences. However, one of the major obstacles faced by scientists engaged in cff-DNA-based prenatal diagnosis is the absence of a universal marker capable of representing the presence of cff-DNA in the samples used. To date, the low levels of cff-DNA in maternal plasma often lead cff-DNA-based prenatal diagnosis to generate false positives or false negatives (Liao et al, 2014).

The present study used a short-tandem repeat [STR] CODIS i.e. loci CSFO1, THOI, TPOX. The three loci have a high discriminatory value in Indonesia's population (Joachim B, et al, 1999). Therefore, one alternative proposed to overcome some of the above obstacles is to use the foetal and maternal genetic variations as a candidate universal marker. However, as with the 
constraints encountered in the previous strategy, genetic variation-based approaches also require a universal marker that can be used to serve as a benchmark against which to determine the results obtained at the end of the analysis derived from the foetus as well as to accurately represent the foetal condition.

Thus, several scientists began to develop a novel epigenetic-based approach to cff-DNAbased prenatal diagnosis (Albert, 1994). Such an epigenetic-based approach began with the discovery of the fact that the maternal maspin gene promoter (SERPINB5) underwent hypermethylation and, conversely, the foetal maspin gene promoter underwent hypomethylation (Strah D, et al, 2015). Further studies showed that placental-derived hypomethylated maspin can be found in all of the samples unaffected by genetic differences and genetic variations in the foetus. Thus, the maspin gene promoter as found in the epigenetic-based approach can be used as a candidate universal marker of the presence of foetal DNA in maternal plasma (Liao et al, 2014). However, the use of unmethylated maspin gene promoter as a candidate universal marker of foetal DNA is very difficult. This is because the isolation of the unmethylated maspin gene promoter from a pool of genes or DNA sequences which are maternally derived and mostly in a methylated state can only be done by using bisulfite which relatively remains very difficult (Strah D, et al., 2015). In addition to requiring a very complicated and intensive procedure, the use of bisulfite on DNA samples may potentially cause damage to the DNA samples up to $96 \%$ of the time (Butler et al, 2004). Thus, the use of the unmethylated-maspin gene promoter as an universal marker for cffDNA-based prenatal diagnosis needs to be reviewed, especially with regard to its routine use in medical applications in hospitals (Connor et al, 1992).

\section{CONCLUSION}

DNA isolated from the maternal plasma of first-trimester pregnant women can be an alternative material in a paternity test, which is a non-invasive technique. The present study used the loci THO1, TPOX and CSF1PO. The use of these loci constitutes a reasonable, strong and efficient method in forensic cases. Under certain conditions, the reference materials can be taken from all nucleated cells on the body of an individual or from another individual with close (kinship) relationship, e.g., brothers (siblings) and parents.

\section{REFERENCE}

[1] Albert B1. Molecular biology of the cell.3nd ed. New York, Garland Publishing; pp 655.

[2] Barden, E. M.. Body composition in children with sickle cell disease. Am J Clin Nutr 2002; 76: 218 .

[3] Bhaskar SN. Orban's Oral Histology and Embryology, eleventh edition, Mosby Year Book, London, pp 298-300

[4] Butler, J.M, Yin Shen; Bruce R. M. The Development of Reduced Size STR Amplicons as Tools for Analysis of Degraded DNA. National Institute of Standards and Technology

[5] Connor M and Ferguson-Smith M. Essential Medical Genetics, Fifth edition, Blakwell Science Ltd, Australia, pp 3 $-29$

[6] Farley, A. Mark. Forensic DNA technology. Michigan: Lewis Publishers Inc, USA.

[7] Joachim Burger, Susanne Hummel, Bernd Herrmann, Winfried Henke. DNA preservation: A microsatellite-DNA study on ancient skeletal remains. Electrophoresis, 20, 1722 \pm 1728

[8] Liao JWG, Ann MG, Zhao Zhen. Non Invasive prenatal testing using free foetal DNA in maternal circulation. Clinica Chimica Acta 428 [2014], 44-50

[9] Saiki RK. The design and optimization of the PCR.in PCR technology principles and applications for DNA amplification. Erlich HA,ed. Stocton Press, New York.

[10] Strah D, Petra O, Janes B. Non-invasive pre natal cell free foetal DNA testing for down syndrome and other chromosome abnormalities. Zdrav Vestn. November 2015 